\title{
SEDIMENT QUALITY OF THE ECOREGION ENGURE, GULF OF RIGA, ASSESSED BY USING ECOTOXICITY TESTS AND BIOMARKER RESPONSES
}

\author{
leva Putna*,**\#, Evita Strode*, leva Bārda**, Ingrīda Puriṇa*,**, Elīna Rimša*, \\ Mintauts Jansons ${ }^{\star \star}$, Maija Balode ${ }^{\star \star \star *}$, and Solvita Strāḳe $e^{\star \star}$ \\ * University of Latvia, Faculty of Biology, Kronvalda bulv. 4, Rīga, LV-1586, LATVIA; \\ ieva.putna@Ihei.Iv \\ ** Latvian Institute of Aquatic Ecology, Daugavgrivas 6, Rīga, LV-1048, LATVIA \\ \# Corresponding author
}

Communicated by Viesturs Melecis

The aim of this study was to assess sediment quality in the ecoregion Engure, western coast of the Gulf of Riga, by using sediment ecotoxicity tests with amphipods Monoporeia affinis and Pontogammarus robustoides and selected biomarkers (AChE, GST, GR, CAT, MT) measured in Macoma balthica, to represent different types of biological responses reacting to different stressors. Ecoregion Engure sediments are characterised by comparatively low concentrations of heavy metals, and the area could be considered as unpolluted. Ecotoxicity tests of ecoregion Engure sediments did not show statistically significant (> 20\% mortality) toxic effects. Survival of test organisms ranged from 83 to $100 \%$ and revealed "good quality" of tested sediment. There were no established strong differences between the stations and years regarding biomarkers. The integrated biomarker response index indicated more stressful conditions in station Mērsrags, while MT activity revealed heavy metal pollution in station Engure. In general, heavy metal concentrations, ecotoxicity tests and biomarker responses indicate that the ecoregion Engure is not markedly various and anthropogenically affected.

Key words: Gulf of Riga, biomarkers, ecotoxicity tests, molluscs, amphipods.

\section{INTRODUCTION}

Sediments represent an important component of marine ecosystems in the recycling of nutrients and toxic substances (i.e. sediments serve as a sink, reservoir and also as a source of toxic substances), some of which are bioavailable or become bioavailable as conditions change naturally or anthropogenically. Frequently, sediments are overloaded with contaminants, causing serious threat to coastal ecosystems, sustainability of natural resources and human health. Organism sensitivity to substance toxic properties varies mainly because of differences in metabolic processes and environmental conditions in which they are living (Trautmann et al., 2001).

Toxicity testing of field-collected sediments is an accepted method to evaluate the risk caused by contaminated sediments to aquatic organisms. As animals living in marine sediments play a major role in global biogeochemical cycling, sediment-living and deposit-feeding amphipods are used for ecotoxicological studies to determine pollution of sediments.
Considering that the sensitivity of organisms may be closely related to their habitats, sediment acute ecotoxicity tests were performed with amphipods Monoporeia affinis and Pontogammarus robustoides, which prefer different substrates - muddy and sandy sediments, respectively. $P$. robustoides was used taking into account the tolerance of invasive species to environmental stress conditions (Wiklund et al., 2009; Strode and Balode, 2013). The use of local species is recommended by the SETAC-Europe guide (Anonymous, 1993), because standardised test species do not always answer the locally relevant questions (Chapman and Long, 1983).

Biomarkers complement and improve reliability of chemical analysis data, offering more integral and biologically relevant information on the potential impact of toxic pollutants to the health of organisms (Van der Oost et al., 2003; Cazenave et al., 2009). Moreover, effects at the biochemical level are generally used as an "early warning" signal to assess the effects of contaminants on organisms, due to the sensitivity, ease of application and specificity to pollution 
stress of many biomarkers (Livingstone et al., 1992). Therefore, the use of biomarkers can offer an integrated evaluation of the effects of pollutants in organisms and show the "health status" of a system under investigation (Hansen, 2003; Ferreira et al., 2005).

A set of biomarkers was used to represent different types of biological responses reacting to different stressors. Acetylcholinesterase (AChE) is an enzyme involved in the synaptic transmission of nerve impulses and is primarily inhibited by neurotoxic compounds, such as organophosphates and carbamate pesticides (Bocquene and Galgani, 1998), but also by other pollutants - heavy metals, detergents, cyanobacterial toxins (Guilhermino et al., 1998; Kankaanpää et al., 2002; Lehtonen et al., 2003).

Glutathione-S-transferase (GST) is involved in the phase II of metabolism where it contributes to cell survival by detoxification of xenobiotics (Habig et al., 1974; Sherrat and Hayes, 2002). GST can detoxify a number of commonly used pesticides, like DDT, atrazine, lindane and methyl parathion, either by catalysing formation of GSH-conjugates or by dehalogenation activity (Sherrat and Hayes, 2002).

Glutathione reductase (GR) plays an important role in cellular antioxidant protection and the adjustment process of metabolic pathways, maintaining adequate levels of reduced cellular GSH by reduction of GSSG to GSH in the NADPH-dependent reaction (Massy and Williams, 1965; Carlberg and Mannervik, 1985).

Another antioxidant enzyme, catalase (CAT), is responsible for transformation of reactive oxygen species, i.e. hydrogen peroxide to water and oxygen (Claiborne, 1985; Di Giulio et al., 1989) and can be induced by a wide range of contaminants, including organic xenobiotics and heavy metals (Akcha et al., 2000; Livingstone, 2001; Roméo et al., 2003).

Metallothionein (MT) consists of sulphur-rich metalloproteins with a major function related to the metabolism of essential trace metals, $\mathrm{Cu}$ and $\mathrm{Zn}$. MT also binds $\mathrm{Cd}$ and $\mathrm{Hg}$ and is therefore involved in the detoxification of metals (George and Olsson, 1994; Viarengo et al., 1997).

A large part of ecoregion Engure (located at the western shore of the Gulf of Riga, Baltic Sea) is included in several specially protected natural areas, and this region is considered as relatively unpolluted. Taking into account the reports of the OSPAR Commission about the negative impact of shipping on the marine and brackish water environment, special attention needs to be paid to the ecoregion Engure, since two ports are located there.

The aim of this study was to assess sediment quality in the ecoregion Engure, western part of the Gulf of Riga, by using sediment ecotoxicity tests and selected biomarkers.

\section{MATERIALS AND METHODS}

Study area. Ecoregion Engure is a territory located at the western shore of the Gulf of Riga, Baltic Sea, where a central element is Lake Engure and its catchment area with adjacent region sea. A large part of ecoregion Engure is included in specially protected natural areas: Marine Protected Area „The western coast of the Gulf of Riga” (from the coastline till the depth of $30 \mathrm{~m}$, with the total area $1322 \mathrm{~km}^{2}$ ) and Nature Park ,Engures ezers”. Both of the areas are included in the NATURA 2000 network.

Two ports are located in ecoregion Engure. Mērsrags port (total area 78.35 ha, aquatorium area 30.7 ha) is one of fastest growing ports among small ports of Latvia. It is attracting new cargo types (timber, logs, wood chips, peat etc.), and strengthening fish processing traditions (Stokenberga, 2012) as well as sailing activities. Mērsrags port cargo turnover during 2006-2012 ranged from 275.1 to 500.7 thousand tons (data of the Ministry of Transport). From 2009 to 2013, deepening works of the port channel and water area were performed (Stokenberga, 2012). The Engure port also is one of the Latvian small ports. In the Engure port as in Mērsrags port, a fish processing company is located, therefore, the main activities in the Engure port are connected to fisheries (Fjodorova, 2009). Engure port cargo turnover during 2006-2012 did not exceed 1 thousand tons (data of the Ministry of Transport).

According to the OSPAR Commision reports (Anonymous, 2009a; 2009b), although maritime transportation is considered to be a comparatively environmentally friendly means of transport, shipping has clear impacts on the marine and brackish water environment. Water pollution from ships can come from discharge of operational wastes from ships, including discharge of raw sewage and garbage (litter), release of toxic chemicals used in anti-fouling paints and leaching of heavy metals from anodes, pollution by oil and hazardous or toxic substances from incidental, operational and illegal discharges and pollution and physical impact through loss of ships and cargo. In view of the above, the pollution level in Mērsrags port can be expected to be higher than in the Engure port.

The coastal part of the Gulf of Riga, in comparison with the open sea, is distinguished by more pronounced abiotic factors (temperature, salinity, dissolved oxygen concentration) variability and irregularity, which further affects the seasonal development of phytoplankton and zooplankton their development in coastal waters begins sooner than in the deeper parts of the Gulf. In the upper water layer of the western part of the Gulf of Riga, salinity ranges from 4.4 to $5.9 \mathrm{psu}$, and in the bottom layer from 5.1 to $6.1 \mathrm{psu}$. Dissolved oxygen concentration in the coastal area ranges from 6 to $8 \mathrm{ml} \mathrm{l}^{-1}$ during spring (in the upper water layer). Water $\mathrm{pH}$ values fluctuate from 8.0 to 8.3 and slightly higher values occur in spring with a maximal level 9.0 (Ojaveer, 1995). 
In the western part of the Gulf of Riga sediments occur in a mosaic fashion. In the area from Mērsrags up to Ragaciems, pebbles and boulders with sand and gravel occur along the coast of the Gulf at depth 0-30 m. Many boulders and pebbles are covered by 1-3 mm thick ferro-manganese crusts (Stiebriņ̌̌ and Väling, 1996).

Sampling. Sampling was performed in the western part of the Gulf of Riga - station Mērsrags (depth $25 \mathrm{~m}$ ) and station Engure (depth 29 m) (Fig. 1). Sediment samples for ecotoxicity tests and bivalves Macoma balthica for biomarker activity detection were collected with a Van Veen grab in May 2010 and 2011 on the Latvian Naval Forces flagship A90 "Varonis".

The collected sediments were placed in plastic vials and stored in a refrigerator in darkness (temperature $4{ }^{\circ} \mathrm{C}$ ). Sediments were transported to the laboratory in cooling boxes and tested immediately after transportation.

Sediment samples for granulometric and heavy metal analysis were taken in May 2010. Sampling was performed with a sediment corer $(\varnothing 90 \mathrm{~mm})$. Sediments were sieved for heavy metal analysis; only the fine fraction $(<63 \mu \mathrm{m})$ was used.

A total of $30 \quad M$. balthica specimens were sampled collected, dissected and foot and digestive glands were removed. The tissues were directly transferred into vials and stored in liquid nitrogen, and later at $80{ }^{\circ} \mathrm{C}$ in a freezer.

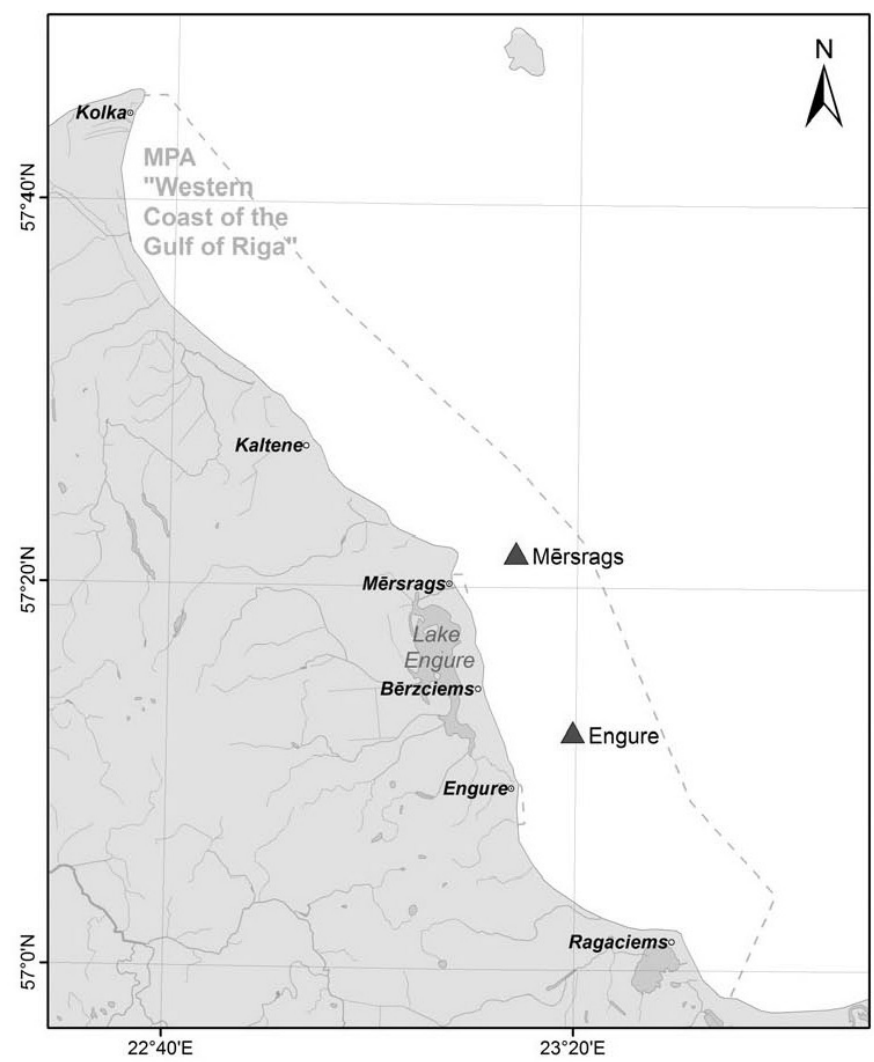

Fig.1. Location of sampling sites (st. Mērsrags and st. Engure) in ecoregion Engure, the Gulf of Riga.
The physicochemical parameters such as salinity, temperature, and dissolved oxygen in the water layer near the bottom surface were measured in both stations using a YSI $6600 \mathrm{~V} 2$ multiparameter water quality probe.

Sediment ecotoxicity. Test organisms collection and handling. Amphipods living in muddy (Monoporeia affinis) and sandy (Pontogammarus robustoides) sediments before the test were collected for bioassays from relatively unpolluted regions located in the open (M. affinis) and coastal $(P$. robustoides) part of the Gulf of Riga (Cederwall, 1997). Amphipods were transported to the laboratory, where they were sorted and the largest predators were removed. Holding and acclimatisation were performed according to Kruschwitz (1987) and US EPA (Anoymous, 2000).

Test procedures. Sediment toxicity was determined using ISO 16712:2005 standard method (Anonymous, 2005) and other similar approaches (Anonymous, 1997; Hay et al., 1998; Borgmann et al., 2005) adapted to the study species. All bioassays were performed at an ecologically relevant temperature and salinity range suitable for each species. These conditions were kept at a constant level during the whole exposure period. After ten days of exposure, sediments were sieved through a $0.5 \mathrm{~mm}$ sieve. Test organisms were transferred in a separate container and the number of living and dead individuals was determined and as well as reburrowing capability of the $M$. affinis was recorded. Survival $(\%)$ of the test organisms after ten-day exposure was used as the main endpoint (Table 1).

Biomarker activity detection. Foot tissue of $M$. balthica was used for the analysis of AChE. Five individuals were pooled per replicate. Determination of AChE activity was conducted according to Bocquené and Galgani (1998) with modification as in Leiniö and Lehtonen (2005). Briefly, foot tissues were homogenised in $0.02 \mathrm{M}$ phosphate buffer $(0.1 \%$ Triton $\mathrm{X}-100, \mathrm{pH} 7.0)$ in ratio $1: 3$ (w/v). The homogenate was centrifuged at $10000 \mathrm{~g}$ for $20 \mathrm{~min}$ and supernatant (S9 fraction) was taken for measuring AChE activity at $412 \mathrm{~nm}$ using a microplate reader (TECAN Infinite 200) (Ellman et al., 1961).

Analyses of GST, GR, CAT and MT activity were made from the same homogenate. Digestive gland tissues were homogenised in cold $100 \mathrm{mM}$ potassium phosphate buffer $(\mathrm{pH} 7.4)$ in ratio $1: 4(\mathrm{w} / \mathrm{v})$. The homogenate was centrifuged at $10000 \mathrm{~g}$ for $20 \mathrm{~min}$.

GST measurements were performed using modification of the method based on Habig et al. (1974). The S9 fraction was diluted with homogenisation buffer in ratio $1: 30$ and the standard reaction mixture contained $20 \mathrm{mM} \mathrm{CDNB}$ and $20 \mathrm{mM}$ GSH.

For GR determination, S9 dilution of $1: 3(\mathrm{w} / \mathrm{v})$ was made and the activity of GR was assayed by the rate of NADPH $(1 \mathrm{mM})$ oxidation in the presence of GSSG $(5 \mathrm{mM})$. The 
TEST CONDITIONS DURING SEDIMENT TOXICITY TESTS WITH AMPHIPODS Monoporeia affinis AND Pontogammarus robustoides

\begin{tabular}{ll}
\hline Test type & Whole sediment toxicity test \\
Test duration & 10 days \\
Temperature & $4{ }^{\circ} \mathrm{C}-M$. affinis (Lindström, 1855) \\
& $16^{\circ} \mathrm{C}-P$. robustoides (Sars, 1894) \\
Size and life stage of amphipods & $2-4$ mm subadults \\
Salinity & $5.6 \pm 2$ psu \\
pH & $7 \pm 1$ \\
Sediment volume & 175 ml (2cm) \\
Overlying water volume & 800 ml \\
Illumination & $500-1000$ lx \\
Test photoperiod & $16: 8$ light/dark \\
Test chamber & 1 L glass beaker \\
Feeding & a mixture of Tetra-Min $®$ fish food \\
Replicates & with algal culture, every second day \\
Number of organisms & 3 \\
Dissolved oxygen & 10 individuals per replicate \\
\hline & $>70 \%$ \\
\hline & control survival $>80 \%$ \\
\hline
\end{tabular}

GR and GST activities were measured with a microplate reader (TECAN Infinite 200) at $340 \mathrm{~nm}$.

CAT activity was determined according to Claiborne (1985) and the S9 fraction was diluted in ratio $1: 10(\mathrm{w} / \mathrm{v})$. CAT activity was measured with a microplate reader (TECAN Infinite 200) by observing decrease of $30 \mathrm{mM} \mathrm{H}_{2} \mathrm{O}_{2}$ at 240 $\mathrm{nm}$.

The quantity of proteins present in homogenate was determined using the method of Bradford (1976) with bovine serum albumin (BSA) as a standard for all biomarkers. All measurements of enzymatic activity and protein content were performed in quadruplicate for each replicate.

The analysis of MT was carried out according to Viarengo et al. (1997). The tissues were homogenised $1: 3$ (w/v) in reducing conditions $(0.05 \mathrm{M}$ sucrose TRIS buffer, $\mathrm{pH}$ 8.6 , containing $0.01 \% \beta$-mercaptoethanol). The homogenates were centrifuged at $30000 \mathrm{~g}$ at $-4{ }^{\circ} \mathrm{C}$ for $20 \mathrm{~min}$. The resulting supernatants were collected and ethanol/chloroform fractionation was used to obtain a partially purified metalloprotein fraction. Concentration of MT was measured by spectrophotometric determination of - $\mathrm{SH}$ groups using Ellman's reagent (DTNB) with GSH as a standard.

Sediment characterisation. Sediment granulometric analy-

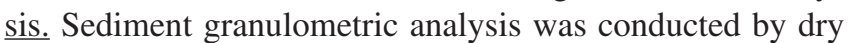
sieving using a "Retsch AS200 control" sieve. Freeze dried sediments were sieved using different mesh sizes in order to obtain four sediment fractions with particle diameter range: $\mu \mathrm{m}$ (medium sand) and $>500 \mu \mathrm{m}$ (coarse sand).

Heavy metal concentrations in sediments. Heavy metal zinc $(\mathrm{Zn})$, copper $(\mathrm{Cu})$, chrome $(\mathrm{Cr})$ nickel $(\mathrm{Ni})$ and manganese $(\mathrm{Mn})$ - concentrations in the sediment fine fraction were measured using a VARIAN SpectrAA-880 atomic absorption spectrometer with flame atomisation. Samples before analyses on atomic absorption spectrometer were digested with nitric acid and hydrogen peroxide in a CEM microwave oven Mars 5 according to the US EPA method SW 3052 (Anonymous, 1996). Concentrations of cadmium $(\mathrm{Cd})$ and lead $(\mathrm{Pb})$ in solutions were determined using a VARIAN SpectrAA 880 Z atomic absorption spectrometer equipped with a GTA 100 graphite tube atomiser. Both metals were determined in concentration calibration mode using wall atomisation with Zeman background correction. Ammonium dihydrogen phosphate and palladium nitrate with magnesium nitrate were applied as matrix modifiers when analysing subsequently $\mathrm{Pb}$ and $\mathrm{Cd}$ with GTA.

Quality control was ensured by the use of blanks and QUASIMEME test materials, which were analysed simultaneously according to the same procedures as the samples.

Data analysis. Data from ecotoxicity tests were expressed as average survival (expressed as percentage) of amphipods between replicates $\pm \mathrm{SD}$. Calculations were made for each test species separately.

Biomarker activity data were expressed as means \pm SD and were first tested for normality using the Shapiro-Wilk test. As all biomarker data were not normally distributed, the Wilcoxon test was used to compare variables between sites and years. Significant difference between variable groups was considered when $P<0.05$. Statistical analyses were performed using the R-2.11.0 software package.

All the measured biomarker responses were combined into one general "stress index", known as the "Integrated Biomarker Response (IBR) index" (Beliaeff and Burgeot, 2002). The procedure described further was used: for each biomarker: (1) calculation of mean and SD for each station; (2) standardisation of data for each station: $x^{\prime} i=$ (xi mean $\mathrm{x}) / \mathrm{s}$, where $\mathrm{x}^{\prime} \mathrm{i}=$ standardised value of the biomarker, $\mathrm{xi}=$ mean value of a biomarker from each station, mean $\mathrm{x}=$ mean of the biomarker calculated for all the stations, and $\mathrm{s}=$ standard deviation calculated for the station-specific values of each biomarker. This gave variance $=1$ and mean $=$ 0 ; (3) using standardized data, $\mathrm{Z}$ was computed as $+\mathrm{x}^{\prime} \mathrm{i}$ in the case of an activation and $x^{\prime} i$ in the case of an inhibition; then the minimum value for all stations for each biomarker was obtained and added to Z; finally the score B was computed as $\mathrm{B}=\mathrm{Z}+|\min |$ where $\mathrm{B} \geq 0$ all the biomarkers were treated this way: (4) calculation of star plot areas by multiplication of the obtained value of each biomarker (Bi) with the value of the next biomarker, arranged as a set, dividing each calculation by 2 and (5) summing all values: $\{[(\mathrm{B} 1 \times$ $\mathrm{B} 2) / 2]+[(\mathrm{B} 2 \times \mathrm{B} 3) / 2]+\cdots$ this resulted in IBR (average of different arrangements of biomarkers in the set). 
Environmental factors. Physico-chemical parameters (salinity, temperature and dissolved oxygen) measured in both sampling stations (st. Mērsrags and st. Engure) are presented in Table 2. All measured physico-chemical parameters differed insignificantly between stations and years.

Sediment characterisation. Sediment granulometric analysis. Results of sediment granulometric analysis are shown in Figure 2. The sediments from st. Engure are dominated by medium sand with a larger fraction of coarse sand and ferromanganese (Fe-Mn) nodules (73 and 21\%, respectively). Sediments from st. Mērsrags are dominated by medium sand and fine sand (87 and 10\%, respectively).

Heavy metal concentrations in sediments. Heavy metal concentrations in sediments of st. Mērsrags and st. Engure are summarised in Table 3. In general, higher concentrations of all analyzed heavy metals were found in st. Engure, especially $\mathrm{Cd}$ (eight times higher) and $\mathrm{Mn}$ (two times higher) $(P<0.05)$.

Sediment ecotoxicity. Results of sediment ecotoxicity tests with Monoporeia affinis and Pontogammarus robustoides are illustrated in Figure 3.

Sediments collected in st. Mērsrags and st. Engure did not show toxic effect. $M$. affinis survival in st. Mērsrags ranged between 93-100\%, and in st. Engure 97-100\%. Bioassays performed with the $P$. robustoides also did not show toxicity of tested sediments. $P$. robustoides survival ranged from $96-100 \%$ in st. Mērsrags and $80-85 \%$ in st. Engure. Although sediment of st. Engure caused slightly higher mor-

Table 2

PHYSICO-CHEMICAL PARAMETERS (TEMPERATURE, SALINITY AND DISSOLVED OXYGEN) IN THE WATER LAYER NEAR THE BOTTOM SURFACE IN STATIONS MĒRSRAGS AND ENGURE

\begin{tabular}{c|c|c|c|c|cc}
\hline \multirow{2}{*}{ Time } & \multicolumn{2}{|c|}{ Temperature $\left({ }^{\circ} \mathrm{C}\right)$} & \multicolumn{2}{c|}{ Salinity (psu) } & \multicolumn{2}{c}{$\begin{array}{c}\text { Dissolved oxygen } \\
(\mathrm{mg} / \mathrm{L})\end{array}$} \\
\cline { 2 - 7 } & Mērsrags & Engure & Mērsrags & Engure & Mērsrags & Engure \\
\hline May 2010 & 1.47 & 1.04 & 5.95 & 5.75 & 13.35 & 13.02 \\
May 2011 & 1.12 & 1.29 & 5.73 & 5.74 & 11.42 & 11.19
\end{tabular}

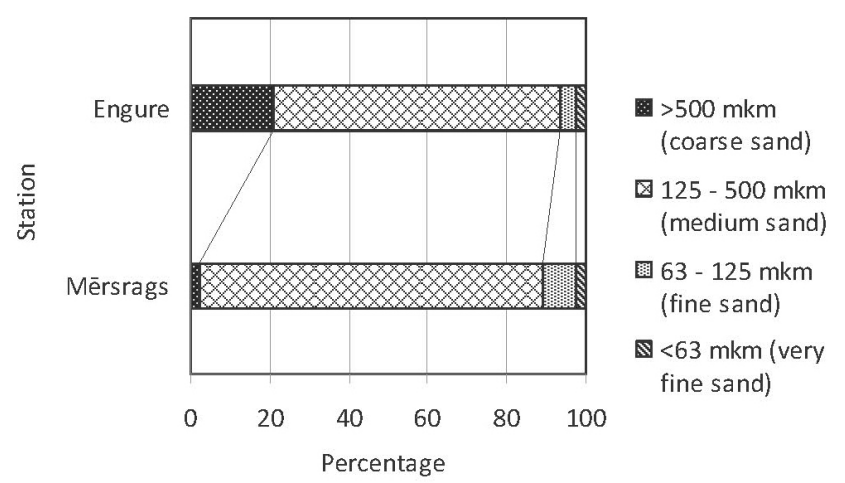

Fig. 2. Results of granulometric analysis illustrating major grain size classes (\%) in station Engure and station Mērsrags.
$\mathrm{Zn}, \mathrm{Cu}, \mathrm{Ni}, \mathrm{Cr}, \mathrm{Cd}, \mathrm{Pb}, \mathrm{Mn}$ CONCENTRATIONS (mg/kg) IN THE SEDIMENTS OF STATIONS MĒRSRAGS AND ENGURE

\begin{tabular}{l|l|c|c|c|c|c|c|c}
\hline Time & Station & $\begin{array}{c}\mathrm{Zn} \\
\mathrm{mg} / \mathrm{kg}\end{array}$ & $\begin{array}{c}\mathrm{Cu} \\
\mathrm{mg} / \mathrm{kg}\end{array}$ & $\begin{array}{c}\mathrm{Ni} \\
\mathrm{mg} / \mathrm{kg}\end{array}$ & $\begin{array}{c}\mathrm{Cr} \\
\mathrm{mg} / \mathrm{kg}\end{array}$ & $\begin{array}{c}\mathrm{Cd} \\
\mathrm{mg} / \mathrm{kg}\end{array}$ & $\begin{array}{c}\mathrm{Pb} \\
\mathrm{mg} / \mathrm{kg}\end{array}$ & $\begin{array}{c}\mathrm{Mn} \\
\mathrm{mg} / \mathrm{kg}\end{array}$ \\
\hline Year & Mērsrags & 87.00 & 18.30 & 25.70 & 44.10 & 0.16 & 57.10 & 727.00 \\
2010 & Engure & 122.00 & 22.70 & 36.50 & 52.50 & 1.27 & 64.30 & 1547.00
\end{tabular}

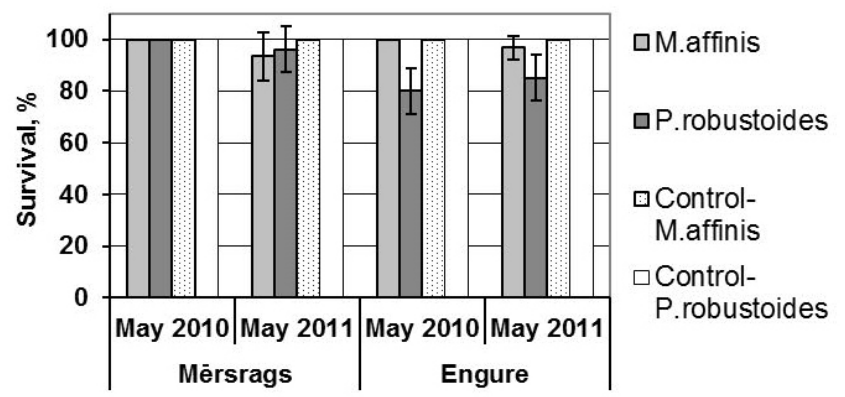

Fig. 3. Ecotoxicity test results $-M$. affinis and $P$. robustoides survival (mean $\pm \mathrm{SD}$ ) in sediments from station Mērsrags and station Engure.

tality of the test organisms, a statistically significant toxic effect was not found.

Biomarker activity. Acetylcholinesterase (AChE) activity showed no significant difference between stations and years $(P>0.05)$. In st. Mērsrags in 2010, AChE activity in foot tissues of $M$. balthica was $18.9 \pm 3.7 \mathrm{nmol} / \mathrm{min} / \mathrm{mg}$, and in 2011: $23.9 \pm 9.2 \mathrm{nmol} / \mathrm{min} / \mathrm{mg}$ protein. In st. Engure AChE activity varied between $22.6 \pm 9.9$ in 2010 and $27.9 \pm 4.1$ $\mathrm{nmol} / \mathrm{min} / \mathrm{mg}$ protein in 2011 (Fig. 4). Although no statistically significant difference between the years and stations was observed, in general, slightly higher AChE activity was observed in 2011 and in st. Engure.

Glutathione-S-transferase (GST) activity in the digestive gland of M. balthica collected in st. Mērsrags in 2010 significantly differed $(P<0.05)$ from that in $2011(321 \pm 156$ and $527 \pm 74 \mathrm{nmol} / \mathrm{min} / \mathrm{mg}$ protein, respectively (Fig. 4)), but in st. Engure it was almost the same in both years (364 \pm 51 and $364 \pm 129 \mathrm{nmol} / \mathrm{min} / \mathrm{mg}$ protein, respectively). In 2011, GST activity was relatively higher in st. Mērsrags.

Glutathione reductase (GR) activity in 2010 was significantly $(P<0.05)$ lower than in 2011 in st. Mērsrags $(7.8 \pm$ 2.2 and $13.9 \pm 2.8 \mathrm{nmol} / \mathrm{min} / \mathrm{mg}$ protein), but insignificantly $(P>0.05)$ in st. Engure $(6.0 \pm 2.4$ and $8.1 \pm 1.3$ $\mathrm{nmol} / \mathrm{min} / \mathrm{mg}$ protein, 2010 and 2011, respectively) (Fig. 4). Comparing GR activity in both stations no significant difference $(P>0.05)$ was detected in 2010, but in 2011 GR activity was significantly higher $(P<0.05)$ in st. Mērsrags.

Catalase (CAT) activity in the digestive gland of $M$. balthica from st. Mērsrags collected in 2011 (37.2 \pm 6.0 $\mu \mathrm{mol} / \mathrm{min} / \mathrm{mg}$ protein) showed significantly lower $(P<$ $0.05)$ values than in $2010(70.1 \pm 3.8 \mu \mathrm{mol} / \mathrm{min} / \mathrm{mg}$ protein $)$ (Fig. 4). The same tendency of lower CAT activity was ob- 
AChE

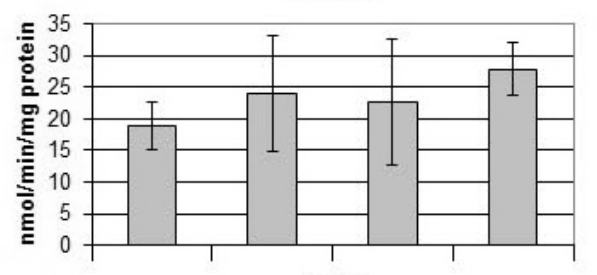

GST

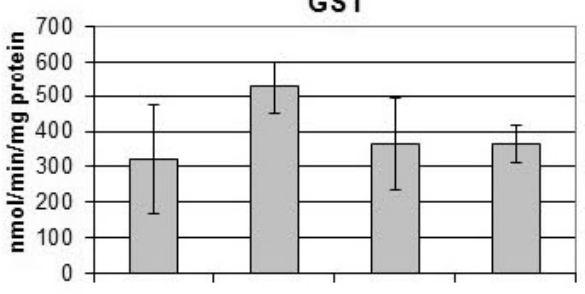

GR

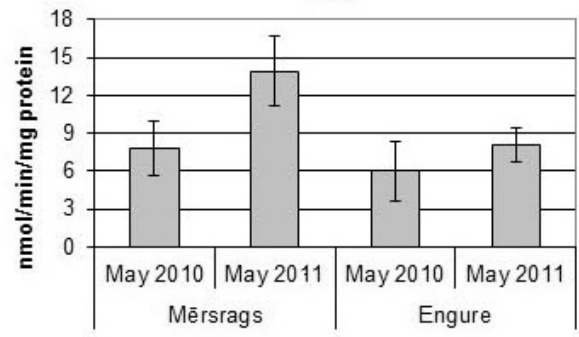

CAT

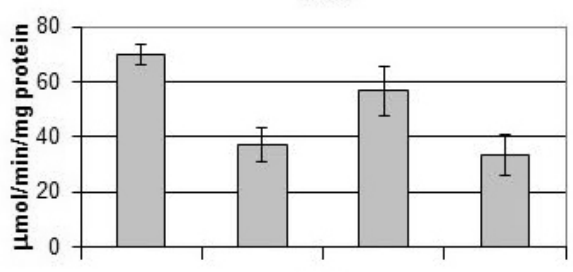

MT

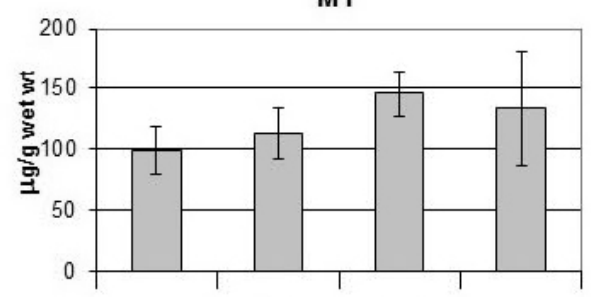

Protein content

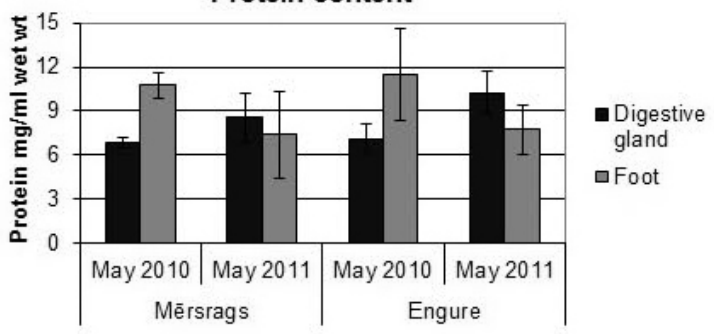

Fig. 4. Biomarker activity (mean $\pm \mathrm{SD})$ in the foot tissue (AChE) and digestive gland (GST, GR, CAT, MT) with corresponding protein content (protein $\mathrm{mg} / \mathrm{ml}$ wet wt) of M. balthica were collected in station Mērsrags and station Engure in the years 2010 and 2011. served for st. Engure - CAT activity between years significantly differed $(56.8 \pm 8.9$ and $33.7 \pm 7.4 \mu \mathrm{mol} / \mathrm{min} / \mathrm{mg}$ protein in 2010 and 2011, repectively). Comparing both stations, no significant CAT activity difference $(P>0.05)$ was observed for each year between the stations.

Metallothionein (MT) activity did not significantly differ between years. In st. Mērsrags MT was $99.1 \pm 19.1$ (2010) and $112.5 \pm 21.0 \mu \mathrm{g} / \mathrm{g}$ wet wt (2011), and in st. Engure $146.4 \pm 18.9(2010)$ and $134.0 \pm 47.0 \mu \mathrm{g} / \mathrm{g}$ wet wt $(2011)$ (Fig. 4). A more pronounced difference of MT activity $(P<$ 0.05 ) between the stations was found only in 2010 .

Integrated biomarker response (IBR) was based on all measured biomarkers and is shown in Figure 5. The area in black integrates the IBR for each site and is represented as a star plot. Higher IBR values and more expressed integrated stress response of $M$. balthica were found in st. Mērsrags in 2010.

\section{DISCUSSION}

Pollution level of ecoregion Engure. It is known that particle size of sediments and the resulting total surface area available for metal adsorption are both important factors in adsorption processes and can affect metal bioavailability (Luoma, 1983). Kulikova and Seisuma (2005) in their research confirmed this for the sediments of the Gulf of Riga. They found that heavy metal concentrations increase with a decrease of the sediment particle size, and therefore our studies of heavy metals in ecoregion Engure were performed using the fine sediment fraction $(<63 \mu \mathrm{km})$.

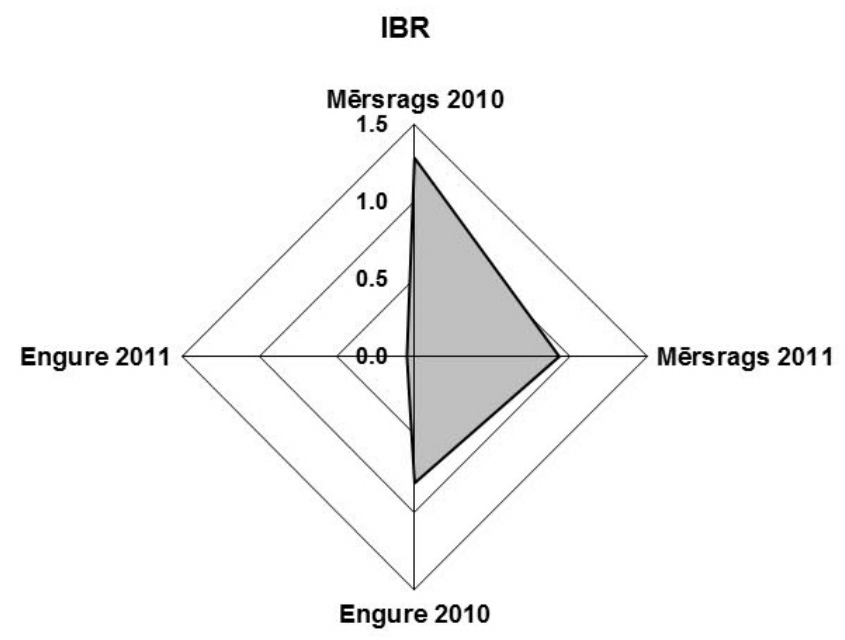

Fig. 5. Integrated biomarker response index (IBR) calculated for station Mērsrags and station Engure in 2010 and 2011 using five measured biomarkers in $M$. balthica.

Ecoregion Engure is characterised by comparatively low concentrations of heavy metals (Table 3). Based on our study results and according to Latvian legislation of heavy metal content limit values in sediments (Anonymous, 2006), Engure and Mērsrags can be considered as unpolluted areas.

In the coastal zone of the Gulf of Riga ( $0.5 \mathrm{~m}$ depth) (Seisuma and Kulikova, 2012), heavy metal concentrations in st. Mērsrags and st. Engure (25-29 m depth) are higher, but lower than in the central part, except for $\mathrm{Pb}$ (Poikāne, 2008). Both stations showed relatively similar values of 
heavy metal concentrations. However, slightly higher concentrations of $\mathrm{Cu}, \mathrm{Ni}, \mathrm{Cr}, \mathrm{Pb}, \mathrm{Zn}$ and significantly higher concentrations of $\mathrm{Cd}$ and $\mathrm{Mn}$ were detected in st. Engure (Table 3), where the presence of coarse sand and a Fe-Mn nodules fraction was detected (Fig. 2).

Previous studies of sediment granulometric analysis in the Gulf or Riga revealed that $\mathrm{Fe}-\mathrm{Mn}$ nodules are present in amounts up to $17 \mathrm{~kg} / \mathrm{m}^{2}$ (Glasby et al., 1997). The high concentration of $\mathrm{Mn}$ in ferromanganese nodules (Glasby et al., 1997; Baturin and Dubinchuk, 2009) can explain the relatively high Mn concentrations in Engure sediments. $\mathrm{Cd}$ is associated with Fe-Mn oxides (Zhong et al., 2013) which explains increased Cd concentrations in Engure, shown also for other Gulf of Riga regions where Cd is scavenged by organic particles and Mn oxihydroxide (Poikāne, 2008).

One of the main reasons for higher heavy metal concentrations in st. Engure could be waste waters that are discharged from waste water treatment plants located in the Engure port (Strāke et al., 2011). In st. Mērsrags, pollution could be mainly the result of shipping activities. Mērsraga port cargo turnover has increased in the last decades (Anonymous, 2009a). It is known that harmful and toxic substances like tributyltin, irgarol, copper (used as anti-foulants) and zinc, aluminum, cadmium (used in ship anodes for protecting ship hulls from corrosion) can leach from ship coatings and anodes to the sea (Anonymous, 2009b). One pollution source may have been attributed to the deepening of the port basin.

Sediment ecotoxicity. Several species have been extensively used for sediment toxicity testing (Cairns and Mount, 1990) and there is no single biological response or test species that can meet all environmental and legislative requirements for effective toxicity testing (Widdows, 1993; Ingersoll, 1995; Rand et al., 1995). Amphipods have proved to be especially useful and are commonly applied in sediment toxicity tests (Luoma and Ho, 1993), because they are associated with sediments either through their burrowing activity or by ingestion of sediment particles (Luoma, 1983; Reynoldson, 1987; Reynoldson and Day, 1993; Bat, 1998). They are highly sensitive (Swartz et al., 1982; 1985a, b) and their population densities are known to decline along pollution gradients in the field (Bellan-Santini, 1980).

Ecotoxicity tests of ecoregion Engure sediments did not show a statistically significant ( $>20 \%$ mortality) toxic effect. Survival of testorganisms ranged from $83-100 \%$ and revealed "good quality" of tested sediments. However, our results did not indicate a statistically significant toxic impact, and toxicity of sediments slightly varied depending on the test species used and location of stations. A slightly toxic effect was detected in some sediment samples from st. Engure, tested with $P$. robustoides (Fig. 2). The deep water amphipod species $M$. affinis did not show any toxicity signs of tested sediments. Relatively high toxicoresistence of $M$. affinis has been reported previously (Berezina et al., 2013; Strode and Balode, 2013) and partly can be explained by exposure conditions. One of the main reasons of high toxicoresistence of $M$. affinis might be low water exposure temperature. Experiments with $M$. affinis were carried out at relatively lower water temperatures, leading to significantly lower rates of metabolism (Table 1). According to John and Leventhal (1995), an increase of $10{ }^{\circ} \mathrm{C}$ can double biochemical reaction rates. A rise in water temperature by $10{ }^{\circ} \mathrm{C}$ increases the oxygen consumption of the amphipod $M$. affinis by 1.7 times and subsequently the metabolism of the species at $16{ }^{\circ} \mathrm{C}$ would be two-times higher than at $5{ }^{\circ} \mathrm{C}$ (Lehtonen, 2004).

Wellbeing of amphipods could be influenced not only by the presence of toxic substances but also by the physical impact of inappropriate sediment grain size classes of natural habitats (Fig. 2). Considering the results of granulometric analysis and sediment conformity to the living environment of amphipods, more appropriate sediments for $M$. affinis could be muddy sediments of st. Mērsrags, whereas for $P$. robustoides - sandy sediments of st. Engure. Nevertheless, our results showed lower survival of $P$. robustoides in st. Engure (Fig. 3), indicating potential toxicity of sediment. One of the reasons for slightly higher toxicity of st. Engure sediments could be due to increased levels of heavy metal concentrations, especially $\mathrm{Cd}$. High sensitivity of amphipods to heavy metals, especially $\mathrm{Cd}$, have been shown also in previous ecotoxicological studies of the Gulf of Riga (Strode and Balode, 2013). Increased levels of pollution in st. Engure have also been found in the study of Berezina et al. (2013).

Biomarker activity. The use of biomarkers is recognised as an important approach for the assessment of pollution, as chemical analysis of environmental samples alone does not provide evidence of the impact of contaminants in biota (Tsangaris et al., 2010).

In this study, slightly lower AChE activity in M. balthica was detected in year 2010. However, no significant differences between stations and years were found. Although inhibition of AChE activity has been proposed as a useful biomarker of effective exposure to organophosphates, carbamates and heavy metals (Bocquene et al., 1990; Bocquene and Galgani, 1998; Fulton and Key, 2001), significant relation with heavy metals and AChE activity in this study area were not found. AChE activity in $M$. balthica from the southern part of the Gulf of Riga (Barda et al., 2014) was in the same range as in the ecoregion Engure (western part of the Gulf of Riga), but higher than in the Gulf of Finland (Leiniö and Lehtonen, 2005; Lehtonen et al., 2006) indicating that the western part of the Gulf of Riga could be less polluted than the Gulf of Finland. Despite the fact that the Gulf of Finland showed relatively lower AChE activity, Lehtonen et al. (2006) suggested that AChE activity results confirmed that organophosphate/ carbamate pesticides are not an environmental problem in Finnish coastal waters and that inhibition of AChE activity could be affected by other factors.

It has been shown that not only pollutants, but also environmental factors such as temperature, salinity, and oxygen 
concentration in the bottom layer affect biomarker activity (Fitzpatrick et al., 1997; Dellali et al., 2001; Manduzio et al., 2004; Pfeifer et al., 2005; Leiniö and Lehtonen, 2005; Bocchetti and Regoli, 2006). In our study, temperature and salinity in sampling stations did not differ significantly between sampling years (Table 2), while dissolved oxygen concentration was higher in 2010. However, studies have shown that dissolved oxygen is not the main factor affecting AChE activity in M. balthica (Leiniö and Lehtonen, 2005, Barda et al., 2014).

Although heavy metals are considered to not be the main pollutant affecting enzyme GST, recent studies in vivo have shown changes of GST activity in fishes after heavy metal exposure (Paris-Palacios et al., 2000). Martín-Díaz et al. (2008) in experimental studies with harbor sediments has shown that several metals (As, $\mathrm{Cd}, \mathrm{Cr}, \mathrm{Cu}, \mathrm{Fe}, \mathrm{Hg}, \mathrm{Mn}, \mathrm{Pb}$ ) induced effects on changes of GST activity of crabs and mussels. In 2010, in the ecoregion Engure, GST activity was slightly higher in st. Engure, but in 2011 - in st. Mērsrags. GST is the main enzyme involved in detoxification reaction, where it catalyses the conjugation of tripeptide glutathione (GSH) with xenobiotics (e.g., polycyclic aromatic hydrocarbons (PAHs) and polychlorinated biphenyls (PCBs). Lehtonen et al. (2006) reported high GST activity in Turku Archipelago region, where the GST values were much higher (1416-3078 $\mathrm{nmol} / \mathrm{min} / \mathrm{mg}$ protein) than in our study. According to Lehtonen et al. (2006), high GST activity in $M$. balthica in Turku Archipelago could be related with increased level of PCBs, DDTs and metals. Although there are no studies about PAHs and PCBs concentrations in the ecoregion Engure, recent assessments of hazardous substances revealed an alarming increase of DDT, PCB, lead, cadmium and zinc in the molluscs and fish of the Gulf of Riga (Anonymous, 2010), especially in the vicinity of harbors and shipping routes. GST concentrations have been claimed to be dependent on environmental factors, but contradictory results have been published (Robillard et al., 2003, Leiniö and Lehtonen, 2005). Studies from the southern part of Gulf of Riga showed no environmental effect on GST activity in M. balthica (Barda et al., 2014). Although our results showed significant increase of GST activity in st. Mērsrags in May 2011, no significant differences of environmental factors (oxygen concentration, temperature and salinity) between the years and stations were observed.

In ecoregion Engure, GR activity showed a similar tendency as GST, while CAT activity was significantly higher in 2010. Enzymes CAT and GR are involved in the enzyme system preventing the cellular damage caused by reactive oxygen species (ROS). Studies have shown that these two enzymes are strongly affected not only by environmental factors (Manduzio et al., 2004, Bocchetti and Regoli, 2006, Verlecar et al., 2008, Barda et al., 2014) and metabolic activities of mussels, but also by different contaminants (Torres et al., 2002; Lehtonen et al., 2006, Martín-Díaz et $a l$., 2008). Taking into account the positive correlation between CAT activity and oxygen concentration, our results of increased CAT activity in 2010 in both stations could partly be explained by increased oxygen concentrations compared to those in 2011 (other environmental parameters did not change between years).

Metallothionein (MT), a biomarker of trace metal exposure, showed higher values in st. Engure where higher levels of heavy metals, especially $\mathrm{Cd}$ and $\mathrm{Mn}$, were detected. The major function of MT is related to the sequestration of essential trace metals $\mathrm{Cu}$ and $\mathrm{Zn}$, but it strongly binds also $\mathrm{Cd}$ and $\mathrm{Hg}$ (Viarengo et al., 2000). It also should be mentioned that MT concentrations are salinity-related in $M$. balthica tissues (Lehtonen et al., 2006). MT detected in the ecoregion Engure (99-146 $\mu \mathrm{g} / \mathrm{g}$ wet wt) were much lower than those detected in the coastal waters of the Gulf of Finland and the Gulf of Gdansk, and thus the western part of the Gulf of Riga can be considered as a relatively unpolluted area.

The integrated biomarker response (IBR) index was developed in order to combine different biomarker signals. The IBR index provides a simple means for a general description of the "health status" of populations (i.e. to assess toxically-induced stress levels of populations (Leiniö and Lehtonen, 2005; Broeg and Lehtonen, 2006; Lehtonen et al., 2006; Damiens et al., 2007). According to our study in st. Mērsrags, in both sampling years IBR was higher than in st. Engure, indicating that in st. Mērsrags conditions for $M$. balthica could be more stressful than in st. Engure. In general, the IBR index indicates that the ecoregion Engure is not much anthropogenically affected.

In conclusion, the ecoregion Engure is characterised by cooperatively low concentrations of heavy metals and can be considered as a relatively unpolluted area. Ecotoxicity tests of the ecoregion Engure sediments did not show statistically significant toxic effects and revealed a "good quality" of tested sediments. Although the integrated biomarker response index indicated more stressful conditions in st. Mērsrags, MT activity revealed heavy metal pollution in st. Engure. In general, heavy metal concentrations, ecotoxicity tests, and biomarker responses indicate that the ecoregion Engure is not much affected by man.

\section{ACKNOWLEDGEMENTS}

This study was supported by the ESF project HYDROTOX contract no. 2009/0226/1DP/.1.1.1.2.0/09/APIA/VIAA/080 and by the project of Latvian Council of Science No. 10.0004. Many thanks to our colleagues from the Latvian Institute of Aquatic Ecology, Vadims Jermakovs for the field work and Maija Viska for paper preparation.

\section{REFERENCES}

Akcha, F., Izuel, C., Venier, P., Budzinski, H., Burgeot, T., Narbonne J.-F. (2000). Enzymatic biomarker measurement and study of DNA adduct formation in benzo[a]pyrene-contaminated mussels, Mytilus galloprovincialis. Aquat. Toxicol., 49, 269-287.

Anonymous (1993). Society of Environmental Toxicology and Chemistry. Guidance document on sediment toxicity assessment for freshwater and 
marine environments. In: Hill, I. R., Matthiessen, P., Heinbach F. (eds.). Workshop on Sediment Toxicity Assessment, Renesse, The Netherlands, 8-10 November 1993 (105 pp.). SETAC-Europe, Brussels.

Anonymous (1996). Microwave assisted digestion of siliceous and organically based matrices (Method 3052). Revision 0 (December 1996). In: Test Methods for Evaluating Solid Wastes: Physical/Chemical Methods, EPA $S W-846$, Third Ed., Vol. I, Section A, Chapter 3 (Inorganic Analytes), pp. 3052-1-3052-20, U.S. Environmental Protection Agency, Office of Solid Waste and Emergency Response, Washington, D.C. Available at: http://www.epa.gov/osw/hazard/testmethods/sw846/pdfs/3052.pdf

Anonymous (1997). JAMP (Joint Assessment and Monitoring Programme) Guidelines for General Biological Effects Monitoring (OSPAR Agreement 1997-7). OSPAR Commission. 22 pp (at pp. 1-12).

Anonymous (2000). Methods for Measuring the Toxicity and Bioaccumulation of Sediment Associated Contaminants with Freshwater Invertebrates. $2^{\text {nd }}$ edition. Report EPA 600/R-99/064 March 2000. Washington, DC: United States Environmental Protection Agency. 212 pp.

Anonymous (2005). International Standards Organization Water Quality Determination of Acute Toxicity of Marine and Estuarine Sediments to Amphipods. ISO/CD 16712:2005(E). First Edition. TC 147/SC5/WG2. 16 pp.

Anonymous (2006). Cabinet Regulation No. 475. Procedures regarding the Cleaning and Deepening of Surface Water Bodies and Port Basins. http://m.likumi.lv/saistitie.php?id=138363\&saistitie_id=7

Anonymous (2009a). Assessment of the Impact of Shipping on the Marine Environment. Prepared by Ware, K. OSPAR Commission. 34 pp.

Anonymous (2009b). Losses of Contaminants from Ships' Coatings and Anodes. A Study Relating to the Netherlands Continental Shelf and the North Sea. Prepared by Tak, van der C. OSPAR Commission. 27 pp.

Anonymous (2010). Hazardous substances in the Baltic Sea - an integrated thematic assessment of hazardous substances in the Baltic Sea. Balt. Sea Environ. Proc., 120B, 1-119.

Barda, I., Purina, I., Rimsa, E., Balode, M. (2014). Seasonal dynamics of biomarkers in infaunal clam Macoma balthica from the Gulf of Riga (Baltic Sea). J. Mar. Syst., 1, 150-156.

Bat, L. (1998). Influence of sediment on heavy metal uptake by the polychaete Arenicola marina. Turkish J. Zool., 22 (4), 341-350.

Baturin, G. N., Dubinchuk V. T. (2009). Composition of ferromanganese nodules from Riga Bay (Baltic Sea). Oceonology (Marine Geology), 49 (1), 121-130

Bellan-Santini, D. (1980). Relationship between populations of amphipods and pollution. Mar. Pollut. Bull., 11, 224-227.

Beliaeff, B., Burgeot, T. (2002). Integrated biomarker response (IBR): A useful graphical tool for ecological risk assessment. Environ. Toxicol. Chem., 21, 1316-1322.

Berezina, N. A., Strode, E., Lehtonen, K. K., Balode, M., Golubkov, S. M. (2013). Sediment quality assessment using Gmelinoides fasciatus and Monoporeia affinis (Amphipoda, Gammaridea) in the northeastern Baltic Sea. Crustaceana, 86, 780-801.

Bocchetti, R., Regoli, F. (2006). Seasonal variability of oxidative biomarkers, lysosomal parameters, metallothioneins and peroxisomal enzymes in the Mediterranean mussel Mytilus galloprovincialis from Adriatic Sea. Chemosphere, 65, 913-921.

Bocquene, G., Galgani, F. (1998). Biological effects of contaminants: Cholinesterase inhibition by organophosphate and carbamate compounds. ICES Tech. Mar. Environ. Sci., 22, 1-12.

Bocquene, G., Galgani, F. (1998). Biological effects of contaminants: cholinesterase inhibition by organophosphate and carbamate compounds. ICES Tech. Mar. Environ., Sci., 22, 1-12.

Bocquene, G., Galgani, F., Truquet, P. (1990). Characterization and assay conditions for use of ACHe activity from several marine species in pollution monitoring. Mar. Environ. Res., 30 (2), 75-89.
Borgmann, U., Norwood, W. P., Nowierski, M. (2005). Amphipod (Hyalella azteca) solid-phase toxicity test using high water-sediment ratios. In: Small-scale Freshwater Toxicity Investigations Toxicity Test Methods (pp. 413-436). Blaise, C., Ferard, J.-F. (eds.). Netherlands: Springer.

Bradford, M. M. (1976). A rapid and sensitive method for quantitation of microgram quantities of protein utilizing the principle of protein dye binding. Anal. Biochem., 72, 248-254.

Broeg, K., Lehtonen K. K. (2006). Indices for the assessment of environmental pollution of the Baltic Sea coasts: Integrated assessment of a multi-biomarker approach. Mar. Poll. Bull., 53, 508-522.

Cairns, J. J., Mount, D. I. (1990). Aquatic toxicology. Part 2. Environ. Sci. Technol., 24, 154-161.

Carlberg, I., Mannervik, B. (1985). Glutathione reductase. Meth. Enzymol., 113, 485-490.

Cazenave, J., Bacchetta, C., Parma, M. J., Scarabotti, P. A., Wunderlin, D. A (2009). Multiple biomarkers responses in Prochilodus lineatus allowed assessing changes in the water quality of Salado River basin (Santa Fe, Argentina). Environ. Poll., 157, 3025-3033.

Cederwall, H. (1977). Annual macrofauna production of a soft bottom in the northern Baltic Proper. In: Keegan, B. F., Ceidigh, P. O., Boaden, P. J. S (eds.). Biology of Benthic Organisms. Proceedings of the $11^{\text {th }}$ European Marine Biology Symposium, Galway, October 1976 (pp. 155-164). Oxford: Pergamon Press.

Chapman, P. M., Long, E. R. (1983). The use of bioassays as part of a comprehensive approach to marine pollution assessment. Mar. Poll. Bull., 14, $81-84$

Claiborne, A. (1985). Catalase activity. In: Greenwald, R. A. (Ed.). Handbook of Methods for Oxygen Radical Research (pp. 283-284). Boca Raton, Florida: CRC Press.

Dellali, M., Gnassia Barelli, M., Romeo, M., Aissa, P. (2001). The use of acetylcholinesterase activity in Ruditapes decussatus and Mytilus galloprovincialis in the biomonitoring of Bizerta lagoon. Comp. Biochem. Physiol., C 130, 227-235.

Damiens, G., Gnassia-Barelli, M., Loquès, F., Roméo, M., Salbert, V. (2007). Integrated biomarker responses index as a useful tool for environmental assessment evaluated using transplanted mussels. Chemosphere, 66, 574-583

Di Giulio, R. T., Wasburn, P. C., Wenning, R. J., Winston, G.W., Jewell, C. S. (1989). Biochemical responses in aquatic animals: A review of determinants of oxidative stress. Environ. Toxicol. Chem., 8, 1103-1123.

Ellman, G. L., Courtney, K. O., Andrres, V., Featherstone, R. M. (1961). A new and rapid colorimetric determination of acetylcholinesterase activity. Biochem. Pharmacol., 7, 88-95.

Ferreira, M., Moradas-Ferreira, P., Reis-Henriques, M. A. (2005). Oxidative stress biomarkers in two resident species, mullet (Mugil cephalus) and flounder (Platichthys flesus), from a polluted site in River Douro Estuary Portugal. Aquat. Toxicol., 71, 39-48.

Fitzpatrick, P. J., O’Halloran, J., Sheehan, D., Walsh, A. R. (1997). Assessment of a glutathione S-transferase and related proteins in the gill and digestive gland of Mytilus edulis (L.), as potential organic pollution biomarkers. Biomarkers, 2, 51-56.

Fjodorova, R. (2009). Katram savs ceḷš ejams [Everybody has one's own way to go]. Grām: Freiberga, A. (red.). Latvijas Jūrniecības gadagrāmata 2008 [Latvian Maritime Yearbook 2008] (352.-358. 1pp.). Rīga: Latvijas Jūrniecības savienība (in Latvian).

Fulton, M. H., Key, P. B. (2001). Acetylcholinesterase inhibition in estuarine fish and invertebrates as an indicator of organophosphorus insecticides exposure and effects. Envion. Toxicol. Chem., 20, 37-45.

George, S. G., Olsson, P. E. (1994). Metallothioneins as indicators of trace metal pollution. In: Kramer, K. J. M. (Ed.). Biomonitoring of Coastal Waters and Estuaries (pp. 151-178). Boca Raton, FL: CRC Press. 
Glasby, G. P., Emelyanov, E. M., Zhamoida, V. A., Baturin, G. N., Leipe, T., Bahlo, R., Bonacker, P. (1997). Environments of formation of ferromanganese concretions in the Baltic Sea: A critical review. In: Nicholson, K., Hein, J. R., Bühn, B., Dasgupta, S. (eds.). Manganese, Mineralization: Geochemistry and Mineralogy of Terrestrial and Marine Deposits. Geological Society Special Publication, Vol. 119 (pp. 213-237). London.

Guilhermino, L., Barros, B., Silva, M. C., Soares, A. M. V. M. (1998). Should the use of inhibition of cholinesterases as a specific biomarker for organophosphate and carbamate pesticides be questioned? Biomarkers, $\mathbf{3}$, $157-163$.

Habig, W. H., Pabst, M. J., Jakoby, W. B. (1974). Glutathione S-transferases - the first enzymatic step in mercapturic acid formation. J. Biol. Chem., 249, 7130-7139.

Hansen, P. D. (2003). Biomarkers. In: Markert, B. A., Breure, A. M., Zechmeister, H. G. (eds.). Bioindicators and Biomonitors (pp. 203-220). Oxford: Elsevier Science Ltd.

Hay, M. E., Stachowicz, J., Cruz-Rivera, E., Bullard, S., Deal, M. S., Lindquist, N. (1998). Bioassays with marine and freshwater macroorganisms. In: Haynes, K. F., Millar, J. G. (eds.). Methods in Chemical Ecology. 2. Bioassay Methods (pp. 39-141). New York: Chapman and Hall.

Ingersoll, C. G. (1995). Sediment tests. In: Fundamentals of Aquatic Toxicology. $2^{\text {nd }}$ edn. Effects, Environmental Fate, and Risk Assessment (pp. 231-255). Rand, G. M. (Ed.). Washington D.C.: Taylor and Francis Publ.

John, D. A., Leventhal, J. S. (1995). Bioavailability of metals. Ch. 2. In: Preliminary Compilation of Descriptive Geoenvironmental Mineral Deposit Models (pp. 10-19). Edward A. du Bray (Ed.). Denver, Colorado: U.S. Department of the Interior U.S. Geological Survey.

Kankaanpää, H., Vuorinen, P., Sipiä, V., Keinänen, M. (2002). Acute effects of Nodularia spumigena and bioaccumulation of nodularin to brown trout (Salmo trutta L.) under laboratory conditions. Aquat. Toxicol., 61, 155-168.

Kruschwitz, L. G. (1987). Environmental factors controlling reproduction of the amphipod Hyalella azteca. Proc. Okla. Acad. Sci., 58, 16-21.

Kulikova, I., Seisuma, Z. (2005). Spatial and temporal distribution of metal in sediments of the Gulf of Riga (the Baltic Sea). Ekologija (Lithuania), 2, $6-10$.

Lehtonen, K. K., Leinio, S., Schneider, R., Leivuori, M. (2006). Biomarkers of pollution effects in the bivalves Mytilus edulis and Macoma balthica collected from the southern coast of Finland (Baltic Sea). Mar. Ecol. Prog. Ser., 322, 155-168.

Lehtonen, K. K., Kankaanpää, H., Leinio, S., Sipia, V. O., Pflugmacher, S., Sandberg-Kilpi, E. (2003). Accumulation of nodularin-like compounds from the cyanobacteria Nodularia spumigena and changes in acetylcholinesterase activity in the clam Macoma balthica during short-term laboratory exposure. Aquat. Toxicol., 64, 461-476.

Lehtonen, K. K. (2004). Seasonal variations in the physiological condition of the benthic amphipods Monoporeia affinis and Pontoporeia femorata in the Gulf of Riga (Baltic Sea). Aquatic Ecol., 38 (3), 441-456.

Leiniö, S., Lehtonen, K. K. (2005). Seasonal variability in biomarkers in the bivalves Macoma balthica and Mytilus edulis from the northern Baltic Sea. Comp. Biochem. Physiol., C 40, 408-421.

Livingstone, D. R. (2001). Contaminant-stimulated reactive oxygen species production and oxidative damage in aquatic organisms. Mar. Pollut. Bull., 42, 656-666.

Livingstone, D. R., Lips, F., Garcia Martinez, P., Pipe, R. K. (1992). Antioxidant enzymes indigestive gland of the common mussel, Mytilus edulis L. Mar. Biol., 112, 265-276.

Luoma, S. N., Ho, K. T. (1993). The appropriate uses of marine and estuarine sediment bioassays. In: The Handbook of Ecotoxicology (pp. 193-226). Calow, P. (ed.). Oxford: Blackwell.
Luoma, S. N. (1983). Bioavailability of trace metals to aquatic organisms: A review. Sci. Total Environ., 28, 1-22.

Manduzio, H., Monsinjon, T., Galap, C., Leboulenger, F., Rocher, B. (2004). Seasonal variations in antioxidant defenses in blue mussels Mytilus edulis collected from a polluted area: Major contributions in gills of an inducible isoform of $\mathrm{Cu} / \mathrm{Zn}$-superoxide dismutase and of glutathione S-transferase. Aquat. Ecol., 70, 83-93.

Massy, V., Williams, C. H. (1965). On the reaction mechanism of yeast glutathione reductase. J. Biol. Chem., 240, 4470-4481.

Martin-Diaz, M. L., Blasco, J., Sales, D., Del Valls, T. A. (2008). Field validation of a battery of biomarkers to assess sediment quality in Spanish ports. Environ. Poll., 151, 631-640.

Paris-Palacios S., Biagianti-Risbourg S., Vernet G. (2000). Biochemical and (ultra)structural hepatic perturbations of Brachydanio rerio (Teleostei, Cyprinidae) exposed to two sublethal concentrations of copper sulfate. Aquat. Toxicol., 50, 109-124.

Pfeifer, S., Schiedek, D., Dippner, J. (2005). Effect of temperature and salinity on acetylcholinesterase activity, a common pollution biomarker, in Mytilus sp. from the south-western Baltic Sea. J. Exp. Mar. Biol. Ecol., 320, 93-103.

Poikāne, R. (2008). The role of suspended particulate matter and sediment in the dynamics of metals in the gulf of Riga. Doctoral Thesis. University of Latvia, Rìga. 157 pp.

Rand, G. M., Wells, P. G., McCarty, L. S. (1995). Introduction to aquatic toxicology. In: Fundamentals of Aquatic Toxicology. $2^{\text {nd }}$ edn. Effects, Environmental Fate, and Risk Assessment (pp. 3-67). Rand, G. M. (Ed.). Washington D.C.: Taylor and Francis Publ.

Reynoldson, T. B., Day, K. E. (1993). Freshwater sediments. In: Handbook of Ecotoxicology, Vol. 1 (pp. 83-100). Calow, P. (Ed.). London: Oxford Blackwell Scientific Publishers.

Reynoldson, T. B. (1987). Interactions between sediment contaminants and benthic organisms. In: Thomas, R., Evans, R., Hamilton, A., Munavar, M., Reynoldson, T., Sadar H. (eds.). Ecological Effects in situ Sediment Contaminants. Dr. W. Junk Publishers. Reprinted from: Hydrobiologia, 149, 53-66.

Robillard, S., Beauchamp, G., Laulier, M. (2003). The role of abiotic factors and pesticide levels on enzymatic activity in the freshwater mussel Anadonta cygnea at three different exposure sites. Comp. Biochem. Physiol., C 135, 49-59.

Roméo, M., Hoarau, P., Garello, G., Gnassia-Barelli, M., Girard, J. P. (2003). Mussel transplantation and biomarkers as useful tools for assessing water quality in the NW Mediterranean. Environ. Poll., 122, 369-378.

Seisuma, Z., Kulikova, I. (2012). Distribution of metal concentrations in sediments of the coastal zone of the Gulf of Riga and open part of the Baltic Sea. Oceanology, 52 (6), 780-784.

Sherrat, P. J., Hayes, J. D. (2002). Glutathione-S-transferases. In: Ioanides, C. (Ed.). Enzyme Systems that Metabolize Drugs and Other Xenobiotics (pp. 319-352). John Wiley \& Sons, LTD.

Stiebriņš, O., Väling, P. (1996). Bottom Sediments of the Gulf of Riga. Riga, $54 \mathrm{pp}$.

Stokenberga, D. (2012). Mērsraga osta plāno jaunus attīstības virzienus [Mērsrags Port plans new development directions]. Grām.: Freiberga, A. (red.). Latvijas Jūrniecības gadagrāmata 2011 [Latvian Maritime Yearbook 2011] (430.-431. lpp.]. Rîga: Latvijas Jūrniecības savienība (in Latvian).

Strāķe, S., Poikāne, R., Putna, I., Pfeifere, M., Jansons, M., Balode, M., Nakari, T., Sainio, P., Schultz, E., Munne, P. (2011). WP3 Innovative Approaches to Chemical Control of Hazardous Substances: National Report of Latvia. Rīga: Latvian Institute of Aquatic Ecology. 75 pp.

Strode, E., Balode, M. (2013). Toxico-resistance of Baltic amphipod species to heavy metals. Crustaceana, 86 (7-8), 1007-1024. 
Swartz, R. C., Ditsworth, G. R., Schults, D. W., Lamberson, J. O. (1985a) Sediment toxicity to a marine infaunal amphipod: Cadmium and its interaction with sewage sludge. Mar. Environ. Res., 18, 133-153.

Swartz, R. C., De Ben, W. A., Jones, J. K. P., Lamberson, J. O., Cole, F. A. (1985b). Phoxocephalid amphipod bioassay for marine sediment toxicity. In: Cardwell, R. D., Purdy, R., Bahner, R. C. (eds.). Aquatic Toxicology and Hazard Assessment: Seventh Symposium. ASTM STP 854 (pp. 284-307). Philadelphia, PA: American Society for Testing and Materials.

Swartz, R. C., Deben, W. A., Sercu, K. A., Lamberson, J. O. (1982). Sediment toxicity and the distribution of amphipods in Commencement Bay, Washington. Mar. Pollut. Bull., 13, pp. 359-364.

Torres, M. A., Testa, C. P., Gáspari, C., Masutti, M. B., Panitz, C. M. N., Curi-Pedrosa, R., Alves de Almeida, E., Di Mascio, P., Filho, D.W. (2002). Oxidative stress in the mussel Mytella guyanensis from polluted mangroves on Santa Catarina Island, Brazil. Mar. Poll. Bull., 44, 923-932.

Trautmann, N. M., Carlsen, W. C., Krasny, M. E., Cunningham, C. M. (2001). Assessing Toxic Risk: Student Edition and Teacher's Guide. Arlington, VA: National Science Teachers Association. 106 pp.

Tsangaris, C., Cotou, E., Papathanassiou, E., Nicolaidou, A. (2010). Assessment of contaminant impacts in a semi-enclosed estuary (Amvrakikos Gulf, NWGreece): Bioenergetics and biochemical biomarkers in mussels. Environ. Monit. Assess., 161, 259-269.

Received 6 January 2014
Van der Oost, R., Beyer, J., Vermeulen, N. P. E. (2003). Fish bioaccumulation and biomarkers in environmental risk assessment: A review. Environ. Toxicol. Pharmacol., 13, 57-149.

Verlecar, X. N., Jena, K. B., Chainy, G. B. N. (2008). Seasonal variation of oxidative biomarkers in gills and digestive gland of green-lipped mussel Perna viridis from Arabian Sea. Est. Coastal Shelf Sci., 76, 745-752.

Viarengo, A., Ponzano, E., Dondero, F., Fabbri, R. (1997). A simple spectrophotometric method for metallothionein evaluation in marine organisms: An application to Mediterranean and Antarctic molluscs. Mar. Environ. Res., 44, 69-84.

Viarengo, A., Burlano, B., Dondero, F., Marro, A., Fabbro, R. (1999). Metallothionein as a tool in biomonitoring programmes. Biomarkers, 4, 455-466

Viarengo, A., Burlando, B., Ceratto, N., Panfoli, I. (2000). Antioxidant role of metallothioneins: A comparative overview. Cell. Mol. Biol. (Noisy-le-grand), 46, 407-417.

Widdows, J. (1993). Marine and estuarine invertebrate toxicity tests. In: Calow, P. (ed.). Handbook of Ecotoxicology. Vol. 1 (pp. 145-166). London: Oxford Blackwell Science Publoshers.

Wiklund, E. A.-K., Vilhelmsson, S., Wiklund, J. S., Eklund, B. (2009). Contaminants and habitat choice in the Baltic Sea: Behavioural experiments with the native species, Monoporeia affinis, and the invasive genus, Marenzelleria. Estuarine, Coastal Shelf Sci., 81 (2), 238-246.

Zhong, H., Kraemer, L., Evans, D. (2013). Influence of contact time and sediment composition on the bioavailability of $\mathrm{Cd}$ in sediments. Environ. Poll. 173, 11-16.

\section{ENGURES EKOREĢIONA (RĪGAS LĪCIS) SEDIMENTU KVALITĀTE, KAS NOTEIKTA, IZMANTOJOT EKOTOKSICITĀTES TESTUS UN BIOMARĶIERU ATBILDES REAKCIJAS}

Pētījuma mērkiis bija novērtēt Engures ekoreǵiona (Rīgas līča rietumu piekrastes) sedimentu kvalitāti, izmantojot sedimentu ekotoksicitātes testus. Lai noteiktu bioloğiskās atbildes reakcijas uz dažāda veida stresoriem, kā testorganismi pielietotas sānpeldes Monoporeia affinis and Pontogammarus robustoides, un izvēlēti biomarķieri (AChE, GST, GR, CAT, MT), kas noteikti gliemenēs Macoma balthica. Engures ekoreǵionu varētu uzskatīt par nepiesārņotu rajonu, jo tā sedimentus raksturo salīdzinoši zemas smago metālu koncentrācijas. Engures ekoreğiona sedimentu ekotoksicitātes testu rezultāti neuzrādīja statistiski būtisku (>20\% mirstība) toksisko efektu. Testorganismu izdzīvotība bija robežās no 83 līdz 100\% un norādīja uz labu testēto sedimentu kvalitāti. Biomarkieru atbildes reakcijas neuzrādīja būtiskas atšķirības starp stacijām un gadiem. Lai gan integrētais biomarķieru indekss uzrādīja lielāku gliemeņu M. balhtica stresu Mērsraga stacijā, biomarķiera MT aktivitāte liecināja par smago metālu paaugstinātu piesārn,ojumu Engures stacijā. Kopumā smago metālu koncentrācijas, ekotoksicitātes testu un biomarkiieru aktivitātes rezultāti norāda, ka Engures ekoreǵiona sedimentu kvalitāte ir samērā homogēna un nav pakḷauta būtiskai antropogēnai ietekmei. 